\title{
Modelling the factors influencing the selection of the construction equipment for Indian construction organizations
}

\author{
S.V.S. Raja Prasad ${ }^{a^{*}}$
}

${ }^{a}$ Associate Professor, National Institute of Construction Management and Research (NICMAR), Jagan Guda, Shameerpet, Hyderabad, Telangana State, India

\begin{tabular}{l}
\hline C H R O N I C L E \\
\hline Article history: \\
Received January 5, 2016 \\
Received in revised format \\
August 2, 2016 \\
Accepted August 18, 2016 \\
Available online \\
August 18, 2016 \\
\hline Keywords: \\
Construction equipment \\
Interpretive structural modelling \\
Driving power \\
Dependency
\end{tabular}

\begin{abstract}
A B S T R A C T
The contribution of Indian construction sector to the GDP is approximately $10 \%$. Under new government policy, it is anticipated that $\$ 1000$ Billion share for exclusively infrastructure segment would be completed within the next few years. Construction sector in developing country like India still depends on labor and the practice of mechanization, adopting to use of versatile construction equipment is not in force. The need for implementing new technologies and automation is essential to improve the quality, safety and efficiency. To meet the challenges ahead the construction, organizations should focus on utilization of machinery/equipment to achieve desirable results. Modern construction is characterized by the increase in utilization of equipment to accomplish numerous construction activities. The selection of construction equipment often affects the required amount of time and effort. It is therefore important for managements of construction organizations and planners to be familiar with the features of various types of equipment commonly used in construction activities. The selection of appropriate equipment is a crucial decision making process as it involves huge capital investment. The purpose of the present study is to develop a model pertaining to the factors influencing the selection of construction equipment by using interpretive structural modelling and the results indicate that productivity and safety are the important factors in selection of equipment in Indian construction organizations.
\end{abstract}

\section{Introduction}

The process of construction is mainly to transform the design into a structure by utilizing workforce and equipment. Construction equipment is a vital resource in the execution of most construction projects and success of construction organizations is greatly influenced by the selection of equipment for the tasks to be performed. All construction activities require equipment irrespective of type of construction such as horizontal or vertical. Infrastructure projects require utilization of heavy construction machinery (Gransberg et al., 2006). It is difficult to adhere to progress targets in construction projects in absence of appropriate equipment, though the initial investment is high. The

* Corresponding author.

E-mail address: sunku.vsrp@gmail.com (S.V.S. Raja Prasad) 
utilization equipment is vital while construction of high rise structures in the view point of safety of workforce. Selection of equipment with safety controls is equally important to eliminate accidents due to operations of plant and machinery. In addition to safety of workforce, the environmental impacts due to emissions while operation construction equipment is also a major concern for all stakeholders (Guggemos \& Horvath, 2006).

Due consideration is to be given on factors like efficiency, productivity, cost, safety and environmental during selection of construction equipment (Warisa et al., 2014). Acquisition of construction machinery is a crucial decision making process and prior planning is required to assess requirement of equipment at various phases of construction. The role of management is vital regarding decisions pertaining to acquisition of equipment (Tatari \& Skibniewski 2006). Equipment management decisions have significant impacts on the economic viability of construction organizations.

The type of equipment utilized in a construction organization has an impact on the profitability. The equipment should fulfil and capable of executing the construction activity with an objective to achieve the targets. Several factors influence the selection of construction equipment which depends on type of construction. Effective utilization of equipment is needed as huge capital is involved in acquisition of the equipment and under-utilization is cost to the organization. The selection criteria of construction equipment such as site conditions, maintenance, cost, safety, ease of acquisition and technology are crucial factors in the perspective contractors (Samee \& Pongpeng 2016). The effective selection of construction equipment for utilization in a construction project depends on technical efficiency, financial viability and availability. A survey conducted in Malaysian construction industry stated that health, safety and environmental aspects were not prioritized while selection of equipment (Waris et al., 2013).

Information relating to the equipment history under similar conditions of operation in other project sites is useful in equipment selection decision making process (Chinchore, 2014). Multi criteria decision making methods were adopted to select equipment required for construction of roads in hilly terrain in India and validated the results by considering a case study (Singh \& Singh, 2013). The decisions relating to requirement of specific equipment for a project is challenging to the site management and in such cases in depth analysis on rent, buy and lease options is essential otherwise the equipment will remain idle after completion of a project. From the literature, it is noticed that prior to 2000 the selection of equipment is mainly revolve around factors such as useful life, cost of maintenance and operating cost. Now the paradigm was shifted towards factors like reliability, safety and sustainable equipment selection (Siddharth \& Pitroda, 2014).

Previous studies on equipment selection mainly focused on cost criteria and operational efficiency and also observed that there is dearth in research particularly in the field of construction equipment management. The present study is basically developing a model for selection of construction equipment by using interpretive structural modelling relating to Indian construction organizations.

\section{Factors influencing selection of equipment}

The factors influencing the selection construction equipment in Indian construction organizations were identified by conducting extensive literature review and they were based on the experts' opinions in the domain of equipment management. The observations/results of the studies conducted in the field of construction equipment selection are represented in Table 1 . The factors identified from the literature were strongly supported by the experts from both real estate and infrastructure segments of Indian construction industry. The factors are applicable for both the segments of the construction industry. 
Table 1

Factors influencing selection of construction equipment

\begin{tabular}{|c|c|c|c|}
\hline S.no & Factor & Observations / comments & Source \\
\hline 1 & Productivity & $\begin{array}{l}\text { Higher productivity and operational flexibility is } \\
\text { crucial in selection process. }\end{array}$ & $\begin{array}{l}\text { Tatari \& Skibniewski, 2006; } \\
\text { Chan et al., } 2001\end{array}$ \\
\hline 2 & Safety & $\begin{array}{l}\text { Safety controls are to be incorporated to } \\
\text { safeguard occupational health and safety of } \\
\text { employees. } \\
\text { Mechanization of equipment shall not create } \\
\text { new hazards. }\end{array}$ & $\begin{array}{l}\text { Goldenberg \& Shapira, 2007; Idoro, } \\
\text { 2011; Arslan, } 2004\end{array}$ \\
\hline 3 & Cost & $\begin{array}{l}\text { Acquisition of equipment contributes } 36 \% \text { of } \\
\text { the total project cost. } \\
\text { Investment on the equipment management and } \\
\text { policy has impact on the profit. } \\
\text { Investment and equipment policy has a great } \\
\text { impact on the income/ profitability of the project. }\end{array}$ & $\begin{array}{l}\text { Yeo \& Ning, 2006; Arditi et al., 1997; } \\
\text { Tavakoli et al., 1990; Ameh et al., 2010; } \\
\text { Azhar et al., 2008; Creedy } 2005\end{array}$ \\
\hline 4 & $\begin{array}{l}\text { Availability of } \\
\text { spares }\end{array}$ & $\begin{array}{l}\text { Standard and interchangability of spares is } \\
\text { vital. } \\
\text { Keeping the equipment idle due to non } \\
\text { availability of spares is cost to the project. }\end{array}$ & $\begin{array}{l}\text { Prasertrungruang \& Hadikusumo, 2007; } \\
\text { Warisa et al., } 2014\end{array}$ \\
\hline 5 & $\begin{array}{l}\text { Reliability and } \\
\text { maintainability }\end{array}$ & $\begin{array}{l}\text { Cost of maintenance is approximately } 40 \% \text { of } \\
\text { the total project cost. } \\
\text { Easy maintenance, service and repair } \\
\text { Maintenance is to be viewed as investment but } \\
\text { not as cost } \\
\text { Equipment must be available always with } \\
\text { optimum utilization. }\end{array}$ & $\begin{array}{l}\text { Schexnayder \& Hancher, 2009; } \\
\text { Gransberg et al., 2006; Robert et al., } \\
\text { 2006; Arslan, 2004; Eldin \& Mayfield, } \\
2005\end{array}$ \\
\hline 6 & Capacity & $\begin{array}{l}\text { Estimation of production capacity is important } \\
\text { to save time and cost. }\end{array}$ & $\begin{array}{l}\text { Oglesby et al., 2005; Gunduz et al., } \\
2012\end{array}$ \\
\hline 7 & Average life & $\begin{array}{l}\text { Better operating conditions and timely } \\
\text { maintenance increases life }\end{array}$ & $\begin{array}{l}\text { Goldenberg \& Shapira, 2007; Valli \& } \\
\text { Jeyasehar, 2012; Eldin \& Mayfield, } \\
\text { 2005; Haidar et al., } 1999\end{array}$ \\
\hline 8 & $\begin{array}{l}\text { Job } \\
\text { requirements }\end{array}$ & $\begin{array}{l}\text { Matching of equipment to the type of } \\
\text { construction activity is important. }\end{array}$ & Gransberg et al., 2006 \\
\hline 9 & $\begin{array}{l}\text { Operating } \\
\text { conditions }\end{array}$ & $\begin{array}{l}\text { Site conditions have effect on life of } \\
\text { equipment as well as wear and tear of rotating } \\
\text { parts. }\end{array}$ & $\begin{array}{l}\text { Eldin \& Mayfield, 2005; Haidar et al., } \\
1999\end{array}$ \\
\hline 10 & $\begin{array}{l}\text { Training needs } \\
\text { for operator }\end{array}$ & $\begin{array}{l}\text { Regular training to operators on safe } \\
\text { operation/safety and health is important as } \\
\text { majority of the accidents due to construction } \\
\text { machinery are due to faulty operation. }\end{array}$ & Mackenzie et al., 2000; Idoro, 2011 \\
\hline 11 & $\begin{array}{l}\text { Environmental } \\
\text { impacts }\end{array}$ & $\begin{array}{l}\text { Age, horsepower and fuel used, can affect rate of } \\
\text { emissions. } \\
\text { Noise and vibration from equipment shall be } \\
\text { controlled at source. } \\
\text { Emission of particulate matter shall be within } \\
\text { prescribed limits. }\end{array}$ & $\begin{array}{l}\text { Avetisyan et al., 2012; Koo \& } \\
\text { Ariaratnam, 2008; Hajji, } 2013\end{array}$ \\
\hline 12 & Versatility & $\begin{array}{l}\text { Act as a catalyst for the advancement of a } \\
\text { construction industry. }\end{array}$ & Arditi et al., 1997 \\
\hline
\end{tabular}

\section{Materials and methods}

\subsection{Interpretive Structural Modelling(ISM)}

Interpretive structural modelling is a well-designed technique for establishing relationships among related factors. A number of factors may be associated with a complex problem and ISM methodology is useful to identify direct and indirect relationship among factors. ISM methodology develops a model considering into common understandings of relation between factors. ISM technique starts with an 
identification of factors influencing a particular issue and then proceeds with a group solving process (Attri et al., 2013).

\subsubsection{Applications of ISM}

ISM methodology has been adopted by researchers in various domains and its applications are shown in Table 2.

\section{Table 2}

Areas of application of ISM

\begin{tabular}{|c|c|}
\hline Area of application & References \\
\hline $\begin{array}{l}\text { A decision support tool in identification and ranking of performance measures in } \\
\text { automobile supply chain }\end{array}$ & Susana et al \\
\hline To understand the relationships among total quality management practices & Talib et al., 2011 \\
\hline To identify and relationships among factors affect labour productivity in India & Sayali \& Rohan, 2014 \\
\hline $\begin{array}{l}\text { For modelling complex interaction among factors responsible for cost overruns in } \\
\text { construction projects in Oman }\end{array}$ & Alzebdeh et al., 2015 \\
\hline To examine relationship among elements of relating to lean manufacturing in India. & Kumar \& Kumar, 2016 \\
\hline ertain variables to implement lean manufacturing in Indian automobile industry & Naveen et al., 2013 \\
\hline To find relationships among criteria influencing solid waste management practices & $\begin{array}{l}\text { Ming- Lang \& Yuan Hsu, } \\
2011\end{array}$ \\
\hline In risk a & Iyer \& Sagheer, 2010 \\
\hline $\begin{array}{l}\text { To identify barriers in implementation of green supply } \\
\text { industries. }\end{array}$ & Arvind \& Azhar, 2014 \\
\hline
\end{tabular}

\subsubsection{ISM procedure}

The steps involved in ISM process are as follows, (Sudarshan \& Ravikant, 2013)

* Identification of factors relevant to the problem;

* Establishing a contextual relationship between factors;

* Framing a structural self interaction matrix(SSIM) of factors which show pairwise relation;

* Creating a reachability matrix from SSIM and checking it for transitivity;

* Transitivity of a contextual relation is an assumption in ISM , which states that if a factor X is related to $\mathrm{Y}$ and $\mathrm{Y}$ is related to $\mathrm{Z}$, then $\mathrm{X}$ is related to $\mathrm{Z}$;

* Partitioning of the reachability matrix into various levels;

* Drawing a directed graph (diagraph) and delinking transition;

* Converting the diagraph into an ISM model by replacing variable nodes with the statements;

* Reviewing the model and making the changes, if necessary.

\subsubsection{Cross impact multiplication applied to classification}

Cross impact multiplication applied to classification (Matrice d' impacts croises- multiplication applique'a un classment) is abbreviated as MICMAC analysis and it is used to segregate the variables according to their driving power and dependence (Mudgal et al., 2009). The factors are grouped into four clusters: autonomous, dependent, linkage and independent. The three steps involved in MICMAC analysis are,

* Identify relevant variables usually through brain storming or expert opinions; factors relating to topic of interest are identified.

* Build casual relationship between factors

* Identify important factors. 


\section{Results}

ISM model suggests implementing the expert opinions in establishing contextual relationship among factors under consideration. To fulfil this requirement, 50 professional in the domain of plant and machinery from different project sites construction safety were consulted to exercise their opinions. Totally, 32 professionals were responded to participate in this study, all the professionals had more than 20 years of exposure in the field of erection, inspection and operational maintenance of plant and machinery in Indian construction organizations. The twelve factors influencing selection of construction equipment in Indian construction organizations are considered for developing a hierarchical model.

\subsection{Relationship among factors}

To develop a contextual matrix of relationship between factors $(\mathrm{m}, \mathrm{n})$, four symbols $(\mathrm{A}, \mathrm{B}, \mathrm{C}$, and $\mathrm{O})$ were used to express direction of relationship : A - factor $m$ will lead to factor $n, \mathrm{~B}$ - factor $n$ will lead to factor $m, \mathrm{C}$ - factors $m$ and $n$ will lead to each other; $\mathrm{O}$ - factors $m$ and $n$ are not related. By using the symbols, a SSIM was developed basing on the opinions of experts and is shown in Table 3.

Table 3

Structural self interaction matrix (SSIM)

\begin{tabular}{|c|c|c|c|c|c|c|c|c|c|c|c|c|}
\hline Factors & 12 & 11 & 10 & 9 & 8 & 7 & 6 & 5 & 4 & 3 & 2 & 1 \\
\hline 1.Productivity & $\mathrm{A}$ & $\mathrm{A}$ & $\mathrm{A}$ & $\mathrm{A}$ & $\mathrm{A}$ & A & $\mathrm{A}$ & $\mathrm{A}$ & $\mathrm{A}$ & $\mathrm{A}$ & $\mathrm{O}$ & \\
\hline 2.Safety & $\mathrm{A}$ & A & $\mathrm{A}$ & A & A & A & A & A & A & A & & \\
\hline 3. Cost & A & $\mathrm{A}$ & $\mathrm{A}$ & $\mathrm{A}$ & A & A & A & $\mathrm{A}$ & $\mathrm{A}$ & & & \\
\hline 4.Availability of spares & A & A & $\mathrm{A}$ & A & A & A & A & $\mathrm{C}$ & & & & \\
\hline 5.Reliabilityand maintainability & A & A & A & A & A & A & A & & & & & \\
\hline 6.Capacity & A & A & A & A & A & A & & & & & & \\
\hline 7.Average life & $\mathrm{A}$ & A & A & $\mathrm{X}$ & $\mathrm{X}$ & & & & & & & \\
\hline 8.Job requirements & A & $\mathrm{A}$ & A & $\mathrm{X}$ & & & & & & & & \\
\hline 9. Operating conditions & A & A & A & & & & & & & & & \\
\hline 10.Training needs for operator & $\mathrm{C}$ & $\mathrm{C}$ & & & & & & & & & & \\
\hline 11.Environmental impacts & $\mathrm{C}$ & & & & & & & & & & & \\
\hline 12.Versatility & & & & & & & & & & & & \\
\hline
\end{tabular}

\subsubsection{Reachability matrix}

To modify the SSIM into binary reachability matrix, all A, B, and $\mathrm{C}$ are replaced by a digit 1 and ' $\mathrm{O}$ ' by zero. The conversion 1's and 0's are supplemented by following the order for $(m \times n)$ and $(n \times m)$ entries of reachability matrix and is presented in Table 4.

\section{Table 4}

Conversion of entries of reachability matrix

\begin{tabular}{ccc}
\hline Symbol & Entry $(\mathrm{m} \times \mathrm{n})$ & Entry $(\mathrm{n} \times \mathrm{m})$ \\
\hline $\mathrm{A}$ & One & Zero \\
$\mathrm{B}$ & Zero & One \\
$\mathrm{C}$ & One & One \\
$\mathrm{O}$ & Zero & Zero \\
\hline
\end{tabular}

The final reachability matrix was developed by following rule prescribed in Table 4 . The driving power and dependence are shown in Table 5. The driving power for each factor is the total number factors it may impact and dependence is factors impacting it. 
Table 5

Final reachability matrix

\begin{tabular}{lccccccccccccc}
\hline Factors & 1 & 2 & 3 & 4 & 5 & 6 & 7 & 8 & 9 & 10 & 11 & 12 & Power \\
\hline 1.Productivity & 1 & 0 & 1 & 1 & 1 & 1 & 1 & 1 & 1 & 1 & 1 & 1 & 11 \\
2.Safety & 0 & 1 & 1 & 1 & 1 & 1 & 1 & 1 & 1 & 1 & 1 & 1 & 11 \\
3.Cost & 0 & 0 & 1 & 1 & 1 & 1 & 1 & 1 & 1 & 1 & 1 & 1 & 9 \\
4.Availability of spares & 0 & 0 & 0 & 1 & 1 & 1 & 1 & 1 & 1 & 1 & 1 & 1 & 8 \\
5.Reliability and maintainability & 0 & 0 & 0 & 0 & 1 & 1 & 1 & 1 & 1 & 1 & 1 & 1 & 7 \\
6.Capacity & 0 & 0 & 0 & 0 & 0 & 1 & 1 & 1 & 1 & 1 & 1 & 1 & 6 \\
7.Average life & 0 & 0 & 0 & 0 & 0 & 0 & 1 & 1 & 1 & 1 & 1 & 1 & 5 \\
8.Job requirements & 0 & 0 & 0 & 0 & 0 & 0 & 0 & 1 & 1 & 1 & 1 & 1 & 4 \\
9.Operating conditions & 0 & 0 & 0 & 0 & 0 & 0 & 0 & 0 & 1 & 1 & 1 & 1 & 4 \\
10.Training needs for operator & 0 & 0 & 0 & 0 & 0 & 0 & 0 & 0 & 0 & 1 & 1 & 1 & 3 \\
11.Environmental impacts & 0 & 0 & 0 & 0 & 0 & 0 & 0 & 0 & 0 & 0 & 1 & 1 & 2 \\
12.Versatility & 0 & 0 & 0 & 0 & 0 & 0 & 0 & 0 & 0 & 0 & 0 & 1 & 1 \\
Dependence power & 1 & 1 & 3 & 4 & 5 & 6 & 7 & 8 & 9 & 10 & 11 & 12 & \\
\hline
\end{tabular}

\subsection{Level partitioning}

The reachability, antecedent and intersection sets have been derived for all the factors. The factor for which the reachability and intersection sets are the same has been assigned the top level in the hierarchy of ISM. The iterations are continued till the level of each factor is found. The levels assist in building diagraph and hierarchy model of ISM. The first iteration and final iteration are shown in Table 6 and 7 respectively.

Table 6

First iteration

\begin{tabular}{cllcc}
\hline Factor & Reachability set & Antecedent set & Intersection set & Level \\
\hline 1 & $1,3.4,5,6.7,8,9,10,11,12$ & 1 & 1 & \\
2 & $2,3.4,5,6.7,8,9,10,11,12$ & 2 & 2 & \\
3 & $3.4,5,6.7,8,9,10,11,12$ & $1,2,3$ & 3 & \\
4 & $4,5,6.7,8,9,10,11,12$ & $1,2,3,4$ & 4 & \\
5 & $5,6.7,8,9,10,11,12$ & $1,2,3,4,5$ & 5 & \\
6 & $6.7,8,9,10,11,12$ & $1,2,3,4,5,6$ & 7 & \\
7 & $7,8,9,10,11,12$ & $1,2,3,4,5,6,7$ & 8 & \\
8 & $8,9,10,11,12$ & $1,2,3,4,5,6,7,8$ & 9 & \\
9 & $9,10,11,12$ & $1,2,3,4,5,6,7,8,9$ & 10 & \\
10 & $10,11,12$ & $1,2,3,4,5,6,7,8,9,10$ & 11 & \\
11 & 11,12 & $1,2,3,4,5,6,7,8,9,10,11$ & 12 & I \\
\hline
\end{tabular}

Table 7

Final iteration

\begin{tabular}{lllll}
\hline Factor & Reachability set & Antecedent set & Intersection set & Level \\
\hline 1 & $1,3,4,5,6,7,8,9,10,11,12$ & 1 & 1 & XI \\
2 & $2,3,4,5,6,7,8,9,10,11,12$ & 1,2 & 2 & XI \\
3 & $3,4,5,6,7,8,9,10,11,12$ & $1,2,3$ & 3 & $\mathbf{X}$ \\
4 & $4,5,6,7,8,9,10,11,12$ & $1,2,3,4$ & 4 & IX \\
5 & $5,6,7,8,9,10,11,12$ & $1,2,3,4,5$ & 5 & VIII \\
6 & $6,7,8,9,10,11,12$ & $1,2,3,4,5,6$ & 6 & VII \\
7 & $7,8,9,10,11,12$ & $1,2,3,4,5,6,7$ & 7 & VI \\
8 & $8,9,10,11,12$ & $1,2,3,4,5,6,7,8$ & 8 & V \\
9 & $9,10,11,12$ & $1,2,3,4,5,6,7,8,9$ & 9 & IV \\
10 & $10,11,12$ & $1,2,3,4,5,6,7,8,9,10$ & 10 & III \\
11 & 11,12 & $1,2,3,4,5,6,7,8,9,10,11$ & 11 & II \\
12 & 12 & $1,2,3,4,5,6,7,8,9,10,11,12$ & 12 & I \\
\hline
\end{tabular}




\subsection{Driver power and dependence diagram}

Driving power and dependence of factors is analysed by using MICMAC analysis. The factors are classified into four clusters; autonomous, dependent, linkage and independent. Autonomous factors have weak driving and dependence powers and are to be withdrawn from the system. Dependent factors have weak driving and strong dependence power. The linkage cluster has strong driving and dependence powers, and independent cluster have strong driving power and weak dependence power [38, 41and 39]. The driver dependence diagram was constructed and shown in Fig. 1. From the diagram, it is observed that no factor was identified as autonomous. The non existence of factors establishes that all the factors influence the process of selection of equipment in Indian construction organizations. Finally, productivity and safety are treated as the driving factors, which have strong driving power to influence selection of construction equipment.

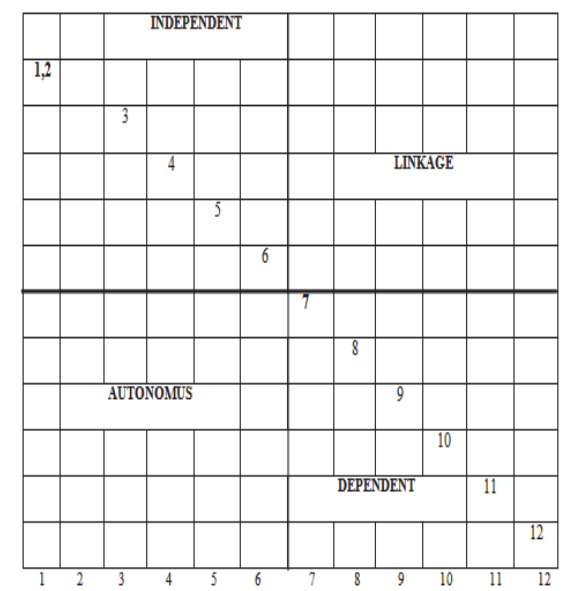

Fig. 1. Driver - dependence diagram

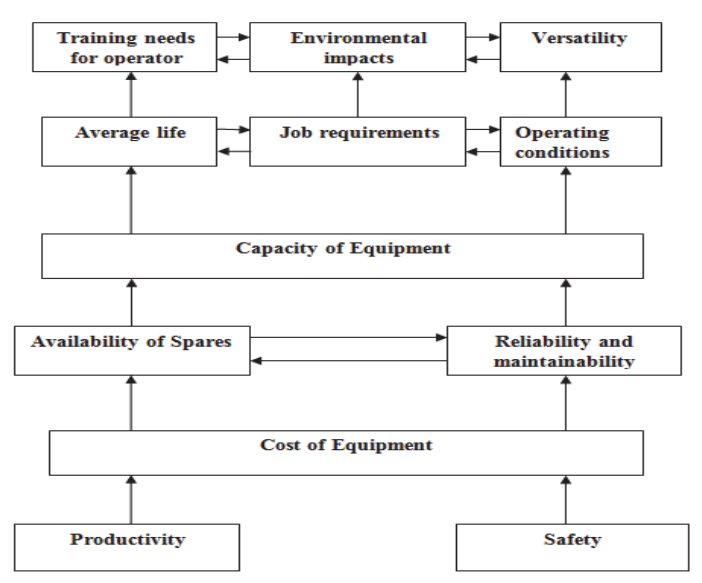

Fig. 2. ISM based hierarchy model

\subsection{Diagraph}

Diagraph is the hierarchy model developed after deleting the transitivity links from the final reachability matrix. The ISM model was represented in Fig 2. The significant factor influencing selection of construction equipment in Indian construction organizations are the "productivity" and "safety" as both the factors is at the base of the ISM hierarchy. The two factors act as a base for selection of equipment. Training needs for operator, environmental impacts and versatility are on the top in the hierarchy have high dependency and low driving power. Cost of equipment influence the factors above it in the hierarchy but influenced by productivity and safety of equipment. Average life of equipment, job requirements and operating conditions also play crucial role in equipment selection process.

\section{Conclusions}

ISM is the classical approach to develop a hierarchy model for the factors influencing selection of construction equipment in Indian construction organizations. The influential factors were identified from extensive literature review and discussions with experts in the domain of construction equipment management. The expert opinions are critical in developing the model. The results are useful to the construction organizations as a guideline for the management to focus on influential factors. Productivity and safety are the independent factors with strong driving power with significant impact on other factors. The model was developed basing on the factors influencing Indian construction industry that is inclusive of real estate and infrastructure segments. Similar models can be developed for a particular project like road works, tunnelling activity, bridge construction, metro construction and 
high rise structures etc., in which case the factors may change and new factors may needs to be incorporated. The identified twelve variables from literature are crucial for selection of equipment.

\section{References}

Alzebdeh, K., Bashir, K.A., \& Al Siyabi, S.K. (2015). Applying interpretive structural modelling to cost overruns in construction projects in the Sultanate of Oman. The Journal of Engineering Research, 12, 53-68.

Ameh, O. J., Soyingbe, A. A., \& Odusami, K. T. (2010). Significant factors causing cost overruns in telecommunication projects in Nigeria. Journal of Construction in Developing Countries, 15(2), 4967.

Arditi, D., Kale, S., \& Tangkar, M. (1997). Innovation in construction equipment and its flow into the construction industry. Journal of Construction Engineering and Management, 123(4), 371-378.

Azevedo, S., Carvalho, H., \& Cruz-Machado, V. (2013). Using interpretive structural modelling to identify and rank performance measures: an application in the automotive supply chain. Baltic Journal of Management, 8(2), 208-230.

Arvind, J., \& Azhar, M. (2014). Analysis of the Barriers for Implementing Green Supply Chain Management Practices: An Interpretive Structural Modelling Approach, $12^{\text {th }}$ Global Congress on Manufacturing and Management. Procedia Engineering, 97, 2157-2166.

Attri, R., Dev, N., \& Sharma, V. (2013). Interpretive structural modelling (ISM) approach: an overview. Research Journal of Management Sciences, 2(2), 3-8.

Avetisyan, H. G., Miller-Hooks, E., \& Melanta, S. (2011). Decision models to support greenhouse gas emissions reduction from transportation construction projects. Journal of Construction Engineering and Management,138(5), 631-641.

Azhar, N., Farooqui, R. U., \& Ahmed, S. M. (2008, August). Cost overrun factors in construction industry of Pakistan. In First International Conference on Construction In Developing Countries (ICCIDC-I), Advancing and Integrating Construction Education, Research \& Practice (pp. 499508).

Cagdac Arslan, M., Catay, B., \& Budak, E. (2004). A decision support system for machine tool selection. Journal of Manufacturing Technology Management, 15(1), 101-109.

Chan, F. T. S., Ip, R. W. L., \& Lau, H. (2001). Integration of expert system with analytic hierarchy process for the design of material handling equipment selection system. Journal of Materials Processing Technology, 116(2), 137-145.

Chinchore, M. N. D. (2014). Planning and selection of heavy construction equipment in civil engineering. International Journal of engineering Research and Applications, 1(4), 29-31.

Creedy, G. (2005). Risk factors leading to cost overrun in highway projects: Paper presented at the Proceeding of Queenland University of Technology Research Week International Conference, Brisbane, Australia.

Eldin, N. N., \& Mayfield, J. (2005). Determination of most economical scrapers fleet. Journal of construction engineering and management,131(10), 1109-1114.

Goldenberg, M., \& Shapira, A. (2007). Systematic evaluation of construction equipment alternatives: case study. Journal of construction engineering and management, 133(1), 72-85.

Gransberg, D.D., Popescu, C.M., \& Ryan, R.C. (2006). Construction Equipment Management for Engineers, Estimators and Owners, Taylor \& Francis, London.

Guggemos, A. A., \& Horvath, A. (2006). Decision-support tool for assessing the environmental effects of constructing commercial buildings. Journal of Architectural Engineering, 12(4), 187-195.

Haidar, A., Naoum, S., Howes, R., \& Tah, J. (1999). Genetic algorithms application and testing for equipment selection. Journal of Construction Engineering and Management, 125(1), 32-38.

Hajji, A. M. (2013). Estimating the emissions of nitrogen oxides (NOX) and particulate matter (PM) from diesel construction equipment by using the productivity model. World Journal of Science, Technology and Sustainable Development, 10(3), 212-228. 
Idoro, G. I. (2011). Effect of mechanisation on occupational health and safety performance in the Nigerian construction industry. Journal of Construction in Developing countries, 16(2), 27-45.

Iyer, K. C., \& Sagheer, M. (2009). Hierarchical structuring of PPP risks using interpretative structural modeling. Journal of Construction Engineering and Management, 136(2), 151-159.

Koo, D. H., \& Ariaratnam, S. T. (2008). Application of a sustainability model for assessing water main replacement options. Journal of Construction Engineering and Management, 134(8), 563-574.

Kumar, N. (2013). Implementing lean manufacturing system: ISM approach.Journal of Industrial Engineering and Management, 6(4), 996.

Kumar, S., \& Kant, R. (2013). Supplier selection process enablers: an interpretive structural modeling approach. International Journal of Mechanical and Industrial Engineering, 3(1), 89-95.

Kumar, R., \& Kumar, V. (2016). Analysis of significant lean manufacturing elements through application of interpretive structural modeling approach in Indian industry. Uncertain Supply Chain Management, 4(1), 83-92.

Mackenzie, S., Kilpatrick, A. R., \& Akintoye, A. (2000). UK construction skills shortage response strategies and an analysis of industry perceptions.Construction Management \& Economics, 18(7), $853-862$

Mudgal, R. K., Shankar, R., Talib, P., \& Raj, T. (2009). Greening the supply chain practices: an Indian perspective of enablers' relationships. International Journal of Advanced Operations Management, 1(2-3), 151-176.

Oglesby, H., \& Parker, A. (2012). Howell, Productivity improvement in construction. McGraw Hill.

Phogat, M. V. S., \& Singh, A. P. (2013). Selection of equipment for construction of a hilly road using multi criteria approach. Procedia-Social and Behavioral Sciences, 104, 282-291.

Prasertrungruang, T., \& Hadikusumo, B. H. W. (2007). Heavy equipment management practices and problems in Thai highway contractors.Engineering, Construction and Architectural Management, 14(3), 228-241.

Robert, I., Peurifoy, P.E., Clifford, J., Schexnayder, P.E., \& Shapira, A. (2006). Construction Planning, Equipment and Methods. International Edition, $7^{\text {th }}$ ed., McGraw-Hill, New York.

Samee, K., \& Pongpeng, J. (2016). Structural equation model for construction equipment selection and contractor competitive advantages.KSCE Journal of Civil Engineering, 20(1), 77-89.

Sandbhor, S., \& Botre, R. (2014). Applying total interpretive structural modeling to study factors affecting construction labour productivity.Australasian Journal of Construction Economics and Building, The, 14(1), 20.

Schexnayder, P.E., \& Hancher, F. (2009). The True Cost of Equipment Failure. $3^{\text {rd }}$ ed., Netta Hook, Germany

Siddharth, J., \& Pitroda, J. (2014) A critical literature review on review on factors affecting in selection of construction equipment. International Journal of Advanced Technology in Engineering and Science, 2(12), 559-567.

Tseng, M. L., \& Lin, Y. H. (2011). Modeling a hierarchical structure of municipal solid waste management using interpretive structural modeling. WSEAS Transactions on Environment and Development, 7(11), 337-348.

Talib, F., Rahman, Z., \& Qureshi, M. N. (2011). An interpretive structural modelling approach for modelling the practices of total quality management in service sector. International Journal of Modelling in Operations Management, 1(3), 223-250.

Tatari, O., \& Skibniewski, M. (2006). Integrated agent-based construction equipment management: Conceptual design. Journal of Civil Engineering and Management, 12(3), 231-236.

Tavakoli, A., Masehi, J. J., \& Collyard, C. S. (1990). FLEET: Equipment management system. Journal of Management in Engineering, 6(2), 211-220.

Valli, P., \& Jeyasehar, C. A. (2012). Genetic algorithm based equipment selection method for construction project using MATLAB tool. Iran University of Science \&amp; Technology, 2(2), 235246. 
Waris,A., Khamidi,M.F., \& Idrus, A. (2013) Heavy equipment acquisition in Malaysian construction industry, Proceedings of the International Symposium on Business, Engineering and Industrial Applications, Kuching, Malaysia.

Waris, M., Liew, M. S., Khamidi, M. F., \& Idrus, A. (2014). Criteria for the selection of sustainable onsite construction equipment. International Journal of Sustainable Built Environment, 3(1), 96110.

Yeo, K. T., \& Ning, J. H. (2006). Managing uncertainty in major equipment procurement in engineering projects. European journal of operational research, 171(1), 123-134.

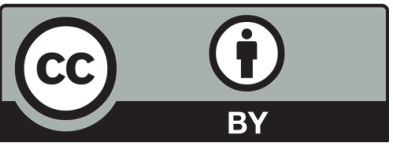

(C) 2016 by the authors; licensee Growing Science, Canada. This is an open access article distributed under the terms and conditions of the Creative Commons Attribution (CC-BY) license (http://creativecommons.org/licenses/by/4.0/). 